\title{
On some relationships between storms and plankton dynamics
}

\author{
F. Peters \\ Institut de Ciències del Mar, CMIMA (CSIC), Pg. marítim de la Barceloneta 37-49, 08003 Barcelona, Catalunya, Spain
}

Received: 24 March 2010 - Revised: 12 April 2010 - Accepted: 31 May 2010 - Published: 30 June 2010

\begin{abstract}
The physico-chemical fields of the pelagic environment are constantly fluctuating at different spatial and temporal scales. Storms are extreme events of such fluctuations that cascade down to small scales to alter nutrient availability to microscopic algae or swimming and mating behaviour of motile plankton. Mediterranean storms sometimes are also responsible for the transport of micro and macronutrients from Saharan origin, albeit the significance for marine production is still under question. In coastal ecosystems, storms represent dissolved nutrient injections via run-off and resuspension that trigger planktonic succession events. Storms may also have a role in the development and mitigation of harmful algal blooms, events with economic and health consequences that are of growing societal concern. Based on laboratory experiments on the effects of turbulence on swimming behaviour and population growth of dinoflagellates, a conceptual sequence of events is proposed for bloom initiation.

Overall, storms affect, directly or indirectly, the dynamics of plankton and hence ecosystem production and cannot be considered catastrophic or hazardous in this context. The full potential of such relationships will be evidenced once biological time series match the resolution and spatial coverage of meteorological and oceanic data. As the frequency and intensity of storms is subject to global change, future oceanic ecosystem production should be affected as well.
\end{abstract}

\section{Introduction}

This contribution may be seen as rather unusual within the regular framework of a Plinius conference for several reasons. First, it relates storms to microscopic sea-life that mostly have no immediate impact on humans and thus deviates from all the subjects addressing the issue from the anthropogenic hazard point of view. Second, it consid-

Correspondence to: F. Peters

(cesc@icm.csic.es) ers storms not as extraordinary events to be avoided but as skewed manifestations of wind and wave variability that conform a natural environmental background important for the understanding and prediction of ecosystem dynamics.

Plankton is the community of organisms, mostly microscopic, floating adrift in the water column. Albeit many planktonic organisms are motile and capable of vertical migration they may not overcome water currents. Thus, plankton live, grow and reproduce in physico-chemical fields that are constantly fluctuating at different spatial and temporal scales. Storms are extreme events of such fluctuations that cascade down to small scales to alter nutrient availability to microscopic algae, or light conditions or swimming and mating behaviour of motile plankton.

This paper will focus mainly on phytoplankton, that is, those planktonic organisms that, like terrestrial plants, use sunlight to convert $\mathrm{CO}_{2}$ into organic carbon building blocks. The total oceanic carbon production is about equal to the total terrestrial carbon production (Field et al., 1998), which gives an idea of the tremendous importance of marine production in global biogeochemical cycling. But plankton, as terrestrial plants, also need other components to grow such as hydrogen, oxygen, phosphorus, nitrogen, sulphur, iron, manganese and the list could go on to the better part of the periodic table. Some of these elements are called nutrients in general terms and some are more readily available than others, some are needed in higher quantity than others and some such as silicon are needed for particular organisms and not others. In any case, algae and other microorganisms tend to exhaust the supply of nutrients in the upper ocean where light for photosynthesis is available. Since part of the production sinks out of the euphotic zone, losing the nutrients that could otherwise be recycled, growth is then limited by the rate of supply of the limiting elements. Internal waves, mesoscale eddies, Langmuir circulation cells, convection, wind-driven turbulence and other processes may increase mixing and enhance diffusivity of nutrients from bottom rich waters or directly entrain deep water. Storms increase the vertical diffusivity, resupplyig nutrients to the upper lit waters.

Published by Copernicus Publications on behalf of the European Geosciences Union. 
Another source of nutrients is atmospheric input of dust particles that may have been transported from long distances. South of the Mediterranean we find the Sahara desert, a globally important source of atmospheric dust (Pérez et al., 2007) that can be experienced in many European locations as red rains. When this dust is deposited over the Mediterranean waters, it may contribute nitrogen, phosphorus, iron, silicate, etc. all important to marine life. Aeolian deposition seems to be important for biogeochemical cycles in geological time frames (Falkowski et al., 1998). In ecological times, signals are harder to discern from background conditions or confounding factors (Cassar et al., 2007; Volpe et al., 2009; Boyd et al., 2010; Guieu et al., 2010). Experiments have shown the fertilizing potential in the Mediterranean (Herut et al., 2005, Pulido-Villena et al., 2010) and system level effects probably depend on the importance of the dust event and the state of the planktonic community.

There are also feedbacks from phytoplankton to weather. Some small phytoplankton known as coccolithoforids will grow massively in warming shallow mixed layers taking advantage of their small size to more effectively scavenge nutrients found in low concentrations. These organisms release sulphur compounds that once in the atmosphere can act as cloud condensation nuclei. Clouds will in turn reduce the radiative forcing and rains and storms release the accumulated energy (Charlson et al., 1987).

Coastal areas are more complex than open ocean waters in terms of the dynamics of the forcing factors that drive plankton. In general terms it seems that an important portion of the variability of open ocean waters can be explained based on the annual dynamics. That is, winter mixing of deep waters brings nutrients to the surface and this sets the initiation of a chlorophyll production peak that largely dominates the annual chlorophyll signal (Longhurst 1998). Although variability exists in the timing and amplitude of this chlorophyll peak and higher frequency events such as storms may alter this pattern (Katara et al., 2008), seasonal signals remain large. In coastal areas a suite of additional forcing factors may episodically introduce nutrients to the system and alter growth and consequently system predictability is decreased. In fact, Cloern and Jassby (2008) have found no universal pattern to predict chlorophyll in coastal areas after analyzing 114 coastal time series. Guadayol et al. (2009a) showed that discharge of the Tordera River, which occurs only after heavy rain, and wave episodes could set off a succession of events in Blanes Bay. Increased nutrient levels were followed by phytoplankton growth and later by other plankton components that were taking advantage of the newly produced organic matter. Thus, in this case storms are crucial in modulating planktonic system dynamics beyond the annual radiative forcing cycle. Unfortunately, storm effects in coastal planktonic areas will not be consistent across sites and depend on local conditions, including anthropogenic foot-printing that will modulate the effect of storms.
There are some algal species that will grow unchecked to a very high biomass (bloom), completely dominating the aquatic community, and even changing the optical properties of water that may appear of different colours depending on the pigments of the species producing such growth. Health concerns arise as some of the species producing this massive growth also produce toxins that may affect directly humans and marine wildlife or humans through the intake of contaminated seafood (Hallegraeff, 2003). Of course, the economic side of the issue is also important as coastal fisheries may have to close temporarily or tourism may be affected. Thus, there is a general interest in trying to understand and predict such outbreaks. Again, causes or triggers do not seem universal and factors include nutrient levels, water mass movement, seeding areas, temperature, predator-prey interactions, and other. Dinoflagellates are the algal group that contribute most harmful bloom species. They are phylogenetically and physiologically diverse and their growth has been classically related to relatively calm conditions (Margalef 1978, Berman and Shteiman 1998). Albeit the group seems to show a sensitivity or tolerance range with respect to fluctuations in the flow, a general trend of a negative effect of turbulence on the growth of these organisms has been summarized in Peters and Marrasé (2000). Small-scale turbulence in upper mixed layers of the ocean is largely wind driven. Storms are able to account for very high turbulence intensities going up to $10^{-5} \mathrm{~W} \mathrm{~kg}^{-1}$ and higher. Some laboratory studies showed that cell division was arrested under turbulence conditions (Pollingher and Zemel, 1981; Berdalet 1992) and it has been suggested that microtubules, involved both in cell division and in the flagella that propel these organisms through water, could be affected (Berdalet 1992, Berdalet et al., 2007). Thus, the main objective of this study was to analyze swimming patterns of dinoflagellates subjected to turbulence.

\section{Material and methods}

Dinoflagellate stock cultures were grown in $250 \mathrm{ml}$ Erlenmeyer flasks. Four species of autotrophic dinoflagellates (Alexandrium minutum, Prorocentrum triestinum, $P$. micans and Akashiwo sanguinea) were grown in $\mathrm{f} / 2$ medium without silicate, at $19^{\circ} \mathrm{C}$ and a 14:10 light:dark cycle, using a mixture of cool white and gro-lux fluorescent light. Heterotrophic Oxyrrhis marina was fed Rhodomonas sp. also grown in f/2 medium without silicate and in the same conditions as autotrophs. Cultures were sampled to monitor cell growth. Once in late exponential phase, experiments were started using the cultures to inoculate fresh medium or food particles.

For the experiments, 4-L spherical Florence flasks were used with $3 \mathrm{~L}$ of culture medium under the same conditions as the stock cultures. Turbulence was generated with an orbital shaker at ca. $2.7 \times 10^{-3} \mathrm{~W} \mathrm{~kg}^{-1}$, estimated using the equations in Guadayol et al. (2009b). Life aliquots were 

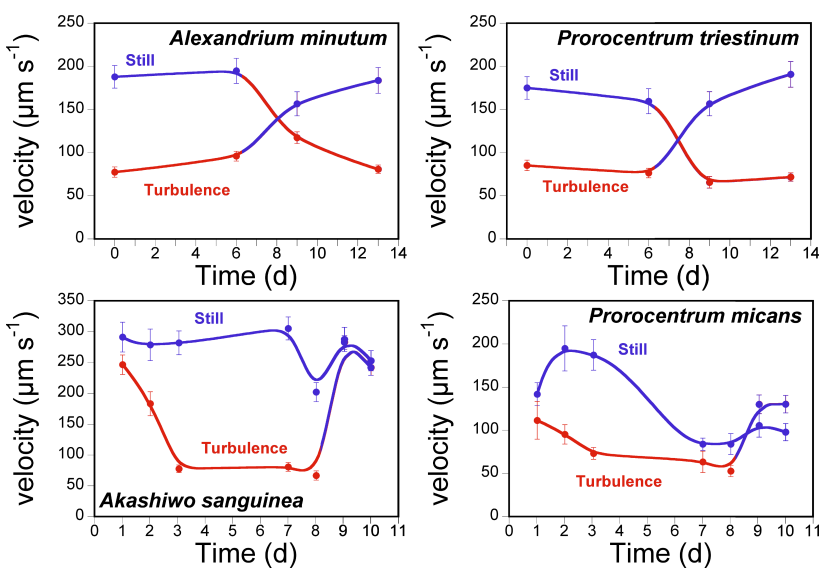

Fig. 1. Swimming velocity of four species of dinoflagellates over time in containers subjected to turbulence (red) or left still (blue).

taken over time, placed in a Palmer counting chamber and the movement of the microorganisms immediately videotaped using a CCD camera connected to a stereomicroscope. Samples were also fixed with Lugol's solution for cell counts. Random video clips were digitised and trajectories (over 1300) analysed using NIH Image (US National Institutes of Health, http://rsb.info.nih.gov nih-image). Swimming velocities were computed from cell positions in consecutive frames and the frame rate.

\section{Results}

A general trend of reduced swimming speed under turbulence became apparent for autotrophic dinoflagellates (Fig. 1). Reduction in velocity lasted for a couple of days until the lower swimming velocity stabilised. This reduction was of 57 to $72 \%$ with respect to the velocity in still water. Re-exposure to calm conditions brought swimming speeds back to normal and population growth was enhanced. Changes in swimming speed were accompanied by changes in turning behaviour, resulting in lower net to gross displacement ratios (data not shown). In the case of the heterotrophic $O$. marina, the reduction in velocity was less apparent with an overall reduction of ca. 11\% (Fig. 2). Both turbulence and still water containers showed a trend of increased swimming velocity over time that was somewhat higher in the still water containers.

Population growth was monitored in detail for $O$. marina (Fig. 3). In the still water container the cells were growing at a specific rate of $0.86 \mathrm{~d}^{-1}$. On the contrary, in the turbulent container the growth rate was reduced to half $\left(0.45 \mathrm{~d}^{-1}\right)$. After $5 \mathrm{~d}$ subjected to turbulence, one container was returned to still conditions and the dinoflagellates started to grow overshooting by far (up to $1.70 \mathrm{~d}^{-1}$ ) the growth rate in the all along still water container.

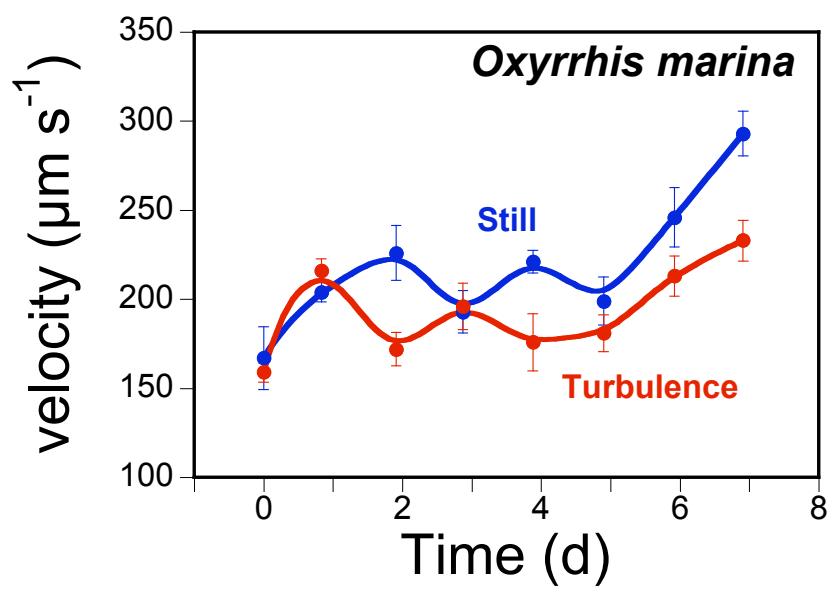

Fig. 2. Swimming velocity of Oxyrrhis marina over time in containers subjected to turbulence (red) or left still (blue).

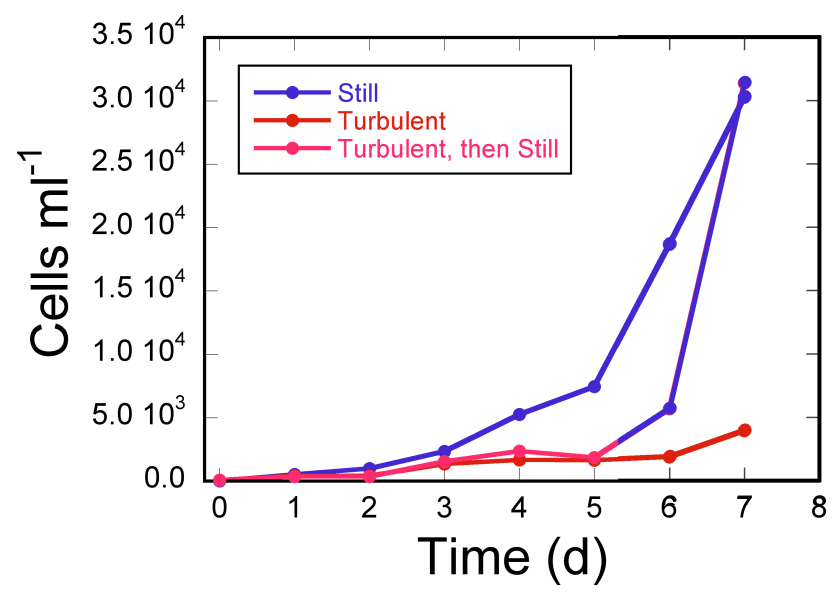

Fig. 3. Increase in cell concentration over time of the dinoflagellate Oxyrrhis marina in containers subjected to turbulence (red), left still (blue) and started turbulent and switched to still at day 5 (pink).

\section{Discussion}

The swimming velocities and population growth of the dinoflagellates studied are affected by turbulence and are in accordance with a generalized view of turbulence affecting the growth of dinoflagellates (Peters and Marrasé 2000; Berdalet et al., 2007). In Karp-Boss et al. (2000), the swimming velocity of single cells also decreased upon exposure to shear while chains of Alexandrium catenella increased in swimming speed in the direction perpendicular to the flow. The swimming velocity of $O$. marina was less affected than the autotrophic species and may indicate a variability in the responses of dinoflagellates as a group as has been suggested by different authors (Peters and Marrasé, 2000; Smayda and Reynolds, 2001; Sullivan and Swift, 2003; Berdalet et al., 2007). Bartumeus et al. (2003) found a change in the swimming behaviour of $O$. marina when exposed to decreased 
food particle concentrations. In our case, there seems to be a tendency to increase swimming speed over time, maybe to maintain encounter rates in a decreasing food particle field. It is worth noting that this trend is larger in still water, where $O$. marina population growth is more conspicuous. Thus, in the case of $O$. marina, turbulence is affecting the swimming, particle encounter or ingestion mechanisms resulting in a lower population growth. Alternatively, turbulence is affecting some other physiological parameter that hinders growth and the trends in swimming velocity are consequence of a different resulting food particle field.

Logistic constraints make it difficult to achieve homogeneous low turbulence conditions in laboratory containers (Guadayol et al., 2009b). As a consequence, the turbulence level assessed in this study is high compared to average natural conditions and would only be found in a heavy storm, close to shore. Thus, the results have to be taken with a certain caution. However, changes in population growth of dinoflagellates under mixing conditions have been reported extensively (White 1976, Pollingher and Zemel 1981, Thomas and Gibson 1990, Berdalet et al. 2007), even for exposures as small as $15 \mathrm{~min} \mathrm{~d}^{-1}$ (Gibson and Thomas 1995), although a certain taxon specific response is present (Smayda and Reynolds 2001, Sullivan and Swift 2003).

At least in some cases, it seems that under turbulence cell cycle division is arrested (Pollingher and Zemel 1981; Berdalet 1992; Berdalet et al., 2007). Even when cell growth is inhibited, the uptake of macronutrients has been shown to increase (García Camacho et al., 2007) which is in accordance with a hydrodynamic increase in nutrient flux towards the cell surface under turbulence (Karp-Boss et al., 1996). Whether all these changes in swimming patterns and cell division are somehow connected through microtubules or otherwise and whether these effects are independent of increased nutrient uptake is not known.

Based on these results I propose a mechanism for bloom initiation (Fig. 4). Many dinoflagellates are active swimmers that migrate daily in the water column. Migration patterns are linked to both light gradients and nutrient supply but also to life cycle processes, including vegetative cell division and encystment. If nutrients are in short supply, dinoflagellates will grow slowly and their biomass will probably be controlled by predators. Strong mixing may increase the concentration of nutrients, and cells will probably actively take them up. If turbulence also interferes with the ability of dinoflagellates to swim and to divide, dinoflagellates will not be able to grow much. Once mixing conditions subside, organisms are free from growing interferences and would be able to readily use the increased nutrient field or the internally stored nutrients, swim and reproduce fast. This hypothetical sequence of events depends on certain environmental conditions including a system with rather depleted nutrients, a strong mixing event that raises the ambient nutrient concentration and lasts at least for a couple of days and a subsequent calm water period. Strong mixing and restratification has been observed

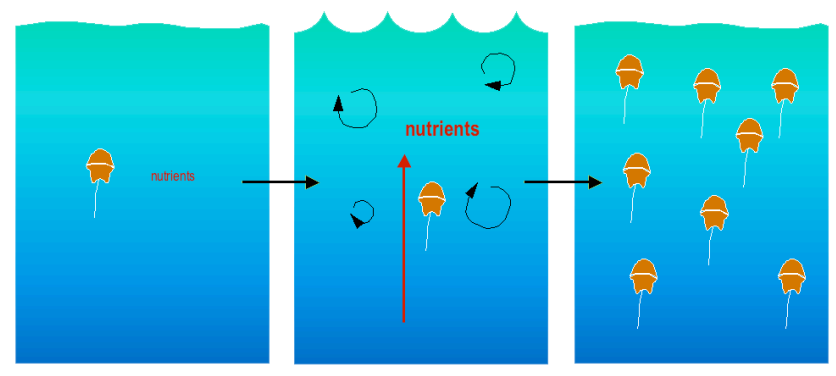

Fig. 4. Proposed conceptual mechanism to help explain the onset of some dinoflagellate blooms. Left panel: dinoflagellates are in low abundance limited by low concentration of nutrients. Central panel: a storm resuspends sediments in a coastal area increasing the level of nutrients in the water column. Dinoflagellates may be able to take these nutrients up but the division process and swimming ability is impaired. Right panel: once storm conditions subside, dinoflagellates are no longer division impaired and may produce a cell outburst.

before the outbreak of some blooms (Berman and Shteiman 1998). Also, in coastal upwelling systems, an injection of nutrients onto the shelf, accompanied by mixing, and a later upwelling relaxation has been proposed as a mechanism to initiate dinoflagellate growth in Spanish rías (Fraga et al., 1988) albeit mainly by organism transport mechanisms (Figueiras et al., 2006). Nutrient concentration and water column stability have been used in a deterministic forecasting model of blooms in Hong Kong (Wong et al., 2007) with some success. It seems that the mechanisms and factors that trigger dinoflagellate outbreaks are varied and complex. The novelty of the present working hypothesis is to add to the suite of mechanisms and to link the larger scale processes to the microscale effects of a strong storm event on growth and swimming.

\section{Conclusions}

It was the purpose of this paper to skim through several interactions of storms with plankton dynamics and to propose a conceptual mechanism to help explain some massive proliferations of algal growth in coastal waters. Storms mix water masses or resuspend sediments in shallow coastal areas that increase the level of nutrients necessary for planktonic life, in a sense as part of the dynamic range of wind-related forcing. In fact, deleterious consequences of storms from an anthropogenic point of view, such as flash floods, beach erosion, dust storms, even benthic marine life destruction, all enhance the basis of marine microscopic life, with important implications in biogeochemical cycles. The study of storms and their consequences is thus crucial to understand marine life dynamics. Even in cases when flow fluctuations may interact negatively with plankton such as with the dinoflagellates that may produce harmful algal blooms, storms may have a role 
in determining the onset, duration or demise of such events that have large human health and economic implications.

We are just at the beginning of our understanding of storms in shaping the dynamics of plankton, and there remain many questions unanswered. Some of such questions relate to the levels of turbulence experienced in laboratory setups, the effect of the exposure time of turbulence on plankton and the relationship with disturbance frequency. Progress in the field is relatively slow as progress in meteorology used to be before synoptic satellite weather pictures and a dense net of automatic meteorological stations feeding data at high frequency. Marine ecologists are eagerly wishing to match such physical, meteorological and even oceanographic data with biological proxies that would tremendously increase our understanding of marine plankton dynamics and our ability to forecast future scenarios as the frequency and intensity of storms is subject to global change.

Acknowledgements. The project "Aproximación multiescalar al estudio de la variabilidad de la producción marina" (CSIC 200830I101) has made the writing of this paper possible. Data shown here and concepts have been generated and developed over the past decade. I am especially indebted to Cèlia Marrasé, Òscar Guadayol, Elisa Berdalet, Rachele Gallisai, Gisela Llaveria, and Estela Romero. I thank Jordi Salat for encouraging me to present my data at the 11th Plinius Conference on Mediterranean Storms.

Edited by: J. Salat

Reviewed by: one anonymous referee

\section{References}

Bartumeus, F., Peters, F., Pueyo, S., Marrasé, C., and Catalan, J.: Helical Lévy walks: adjusting searching statistics to resource availability in microzooplankton, Proc. Natl. Acad. Sci. USA 100: 12771-12775, 2003.

Berdalet, E.: Effects of turbulence on the marine dinoflagellate Gymnodinium nelsonii, J. Phycol. 28, 267-272, 1992.

Berdalet, E., Peters, F., Koumandou, V. L., Roldan, C., Guadayol, O., and Estrada, M.: Species-specific physiological response of dinoflagellates to quantified small-scale turbulence. J. Phycol., 43, 965-977, 2007.

Berman, T. and Shteiman, B.: Phytoplankton development and turbulent mixing in Lake Kinneret (1992-1996), J. Plankton Res., 20, 709-726, 1998.

Boyd, P. W., Strzepek, R., Fu, F., and Hutchins, D. A.: Environmental control of open-ocean phytoplankton groups: Now and in the future, Limnol. Oceanogr. 55, 1353-1376, 2010.

Cassar, N., Bender, M. L., Barnett, B. A., Fan, S., Moxim, W. J., Levy II, H., and Tilbrook, B. The Southern Ocean biological response to aeolian iron deposition, Science. 317, 1067-1070, 2007.

Cloern, J. E. and Jassby, A. D.: Complex seasonal patterns of primary producers at the land-sea interface, Ecol. Lett., 11, 12941303, 2008.

Charlson, R. J., Lovelock, J. E., Andreae, M. O. and Warren, S. G. (1987). Oceanic phytoplankton, atmospheric sulphur, cloud albedo and climate. Nature 326, 655-661.
Falkowski, P. G., Barber, R. T., and Smetacek, V.: Biogeochemical controls and feedbacks on ocean primary production, Science, 281, 200-206, 1998.

Field, C. B., Behrenfeld, M. J., Randerson, J. T., and Falkowski, P.: Primary Production of the Biosphere: Integrating Terrestrial and Oceanic Components, Science, 281, 237-240, 1998.

Figueiras, F. G., Pitcher, G. C., and Estrada, M. in: Harmful algal bloom dynamics in relation to physical processes. edited by: Granéli, E. and Turner, J. T., Ecology of Harmful Algae. Springer, Berlin, Heidelberg, Germany, 127-138, 2006.

Fraga, S., Anderson. D. M., Bravo, I., Reguera, B., Steidinger, K. A., and Yentsch, C. M.: Influence of upwelling relaxation on dinoflagellates and shellfish toxicity in Ria de Vigo, Spain. Estuar. Coast. Shelf S., 27, 349-361, 1988.

García Camacho, F., Gallardo Rodríguez, J. J., Sánchez Mirón, A., Cerón García, M. C., Belarbi, E. H., and Molina Grima, E.: Determination of shear stress thresholds in toxic dinoflagellates cultured in shaken flasks Implications in bioprocess engineering, Proc. Biochem., 42, 1506-1515, 2007.

Gibson, C. H. and Thomas, W. H.: Effects of turbulence intermittency on growth inhibition of a red tide dinoflagellate, Gonyaulax polyedra Stein, J. Geophys. Res.-Ocean. 100, 24841248461995.

Guadayol, Ò., Peters, F., Marrasé, C., Gasol, J. M., Roldán, C., Berdalet, E., Massana, R., and Sabata, A.: Episodic meteorological and nutrient-load events as drivers of coastal planktonic ecosystem dynamics: a time series analysis, Mar. Ecol. Prog. Ser., 381, 139-155, 2009a.

Guadayol, Ò., Peters, F., Stiansen, J. E., Marrasé, C., and Lohrmann, A.: Evaluation of oscillating grids and orbital shakers as generate isotropic and homogeneous small-scale turbulence laboratory enclosures commonly used in plankton, Limnol. Oceanogr.-Meth., 7, 287-303, 2009b.

Guieu, C., Dulac, F., Desboeufs, K., Wagener, T., Pulido-Villena, E., Grisoni, J.-M., Louis, F., Ridame, C., Blain, S., Brunet, C., Bon Nguyen, E., Tran, S., Labiadh, M., and Dominici, J.M.: Large clean mesocosms and simulated dust deposition: a new methodology to investigate responses of marine oligotrophic ecosystems to atmospheric inputs, Biogeosciences Discuss., 7, 2681-2738, 2010,

http://www.biogeosciences-discuss.net/7/2681/2010/.

Hallegraeff, G. M. Harmful algal blooms: a global overview, in: Manual on harmful marine microalgae, edited by: Hallegraeff, G. M., Anderson, D. M., Cembella, A. D., Monographs on oceanographic methodology, Paris, France, UNESCO, 25-49, 2003.

Herut, B., Zohary, T., Krom, M. D., Mantoura, R. F. C., Pitta, P., Psarra, S., Rassoulzadegan, F., Tanaka, T., and Thingstad, T. F.: Response of East Mediterranean surface water to Saharan dust: On-board microcosm experiment and field observations, DeepSea Res. II, 52, 3024-3040, doi:10.1016/j.dsr2.2005.09.003, 2005.

Karp-Boss, L., Boss, E., and Jumars, P. A.: Nutrient fluxes to planktonic osmotrophs in the presence of fluid motion, Oceanogr. Mar. Biol. Ann. Rev. 34, 71-107 1996.

Karp-Boss, L., Boss, E., and Jumars, P. A.: Motion of dinoflagellates in a simple shear flow, Limnol. Oceanogr., 45, 1594-1602, 2000.

Katara, I., Illian, J., Pierce, G. J., Scott, B., and Wang, J.: At- 
mospheric forcing on chlorophyll concentration in the Mediterranean, Hydrobiologia, 612, 33-48, doi:10.1007/s10750-0089492-z, 2008.

Longhurst, A.: Ecological geography of the sea, Academic Press, San Diego, USA, 398 pp., 1998.

Margalef, R.. Life forms of phytoplankton as survival alternatives in an unstable environment. Oceanol. Acta. 1: 493-509, 1978.

Pérez, C., Jiménez, P., Jorba, O., Baldasano, J. M., Cuevas, E., Nickovic, S., and Querol, X.: Long-term trends (1987-2006) of Saharan dust over the Mediterranean and the Canary Islands with the DREAM regional dust model. Geophys. Res. Abstracts 9, 08525, 2007.

Peters, F. and Marrasé, C.: Effects of turbulence on plankton: an overview of experimental evidence and some theoretical considerations. Mar. Ecol. Prog. Ser., 205, 291-306, 2000.

Pollingher, U. and Zemel, E.: In sltu and experimental evidence of the influence of turbulence on cell division processes of Peridinium cinctum forma westa (Lernm) Lefevre, Brit. J. Phycol., 16, 281-287, 1981.

Pulido-Villena, E., Rérolle, V., and Guieu, C. Transient fertilizing effect of dust in P-deficient LNLC surface ocean. Geophys. Res. Lett., 37, L01603, doi:10.1029/2009GL041415, 2010.
Smayda, T. J. and Reynolds, C. S.: Community assembly in marine phytoplankton: application of recent models to harmful dinoflagellate blooms, J. Plankton Res., 23, 447-461, 2001.

Sullivan, J. M. and Swift, E.: Effects of small-scale turbulence on net growth rate and size of ten species of marine dinoflagellates, J. Phycol. 39, 83-94, 2003.

Thomas, W. H. and Gibson, C. H.: Quantified small-scale turbulence inhibits a red tide dinoflagellate, Gonyaulax polyedra Stein, Deep-Sea Res., 37, 1583-1593, 1990.

Volpe, G., Banzon,, V. F., Evans, R. H., Santoleri, R., Mariano, A. J., and Sciarra, R.: Satellite observations of the impact of dust in a low-nutrient, lowchlorophyll region: Fertilization or artifact?, Global Biogeochem. Cy., 23, GB3007, doi:10.1029/2008GB003216, 2009.

White, A. W.: Growth inhibition caused by turbulence in the toxic marine dinoflagellate Gonyaulax excavata, J. Fish. Res. Bd. Can., 33, 2598-2602, 1976.

Wong, K. T. M., Lee, J. H. W., and Hodgkiss, I. J.: A simple model for forecast of coastal algal blooms, Estuar. Coast. Shelf S., 74, 175-196, 2007. 